\title{
A Bodily Sense of Self in Descartes and Malebranche
}

\author{
Colin Chamberlain
}

\begin{abstract}
Although Descartes and Malebranche argue that we are immaterial thinking things, they also maintain that each of us stands in a unique experiential relation to a single human body, such that we feel as though this body belongs to us and is part of ourselves. This paper examines Descartes's and Malebranche's accounts of this feeling. They hold that our experience of being embodied is grounded in affective bodily sensations that feel good or bad: namely, sensations of pleasure and pain, hunger and thirst, and so on. These bodily sensations ground our experiential identification with the body because they represent the body's needs and interests as though they were own, such that we experience an important aspect of our well-being as consisting in the preservation of the body. According to these Cartesians, then, we feel embodied in part because we experience ourselves as having a bodily good.
\end{abstract}

\section{Introduction}

When Descartes is doing metaphysics, he argues that we are immaterial thinking things. ${ }^{1}$ But he also maintains that each of us stands in a unique experiential relation to a single human body, such that we feel as though this body is part of ourselves. In Meditation 6, when the meditator reviews "those things which, as they were perceived by the senses, I previously thought to be true", she ${ }^{2}$ reports, "I sensed that I had a head, hands, feet and other limbs making up the body which I regarded [spectabam] as part of myself, or perhaps even as my whole self"' (M6, AT VII 74/

\footnotetext{
${ }^{1}$ For example, see M2, AT VII 27/CSM II 18; Discourse IV, AT VI 33/CSM I 127; and Search for Truth, AT X 521/CSM II 415. For an explanation of abbreviations, short titles, and citation forms, see "Short Titles and Abbreviations for Primary Texts" at the end of the essay.

${ }^{2}$ To keep Descartes and his fictional narrator (i.e. the meditator) of the Meditations distinct, I shall refer to the meditator with the feminine pronouns "her" and "she". In this case, however, the meditator seems to be speaking for Descartes.

C. Chamberlain $(\triangle)$

Temple University, Philadelphia, PA 19122, USA

e-mail: colin.chamberlain@temple.edu
} 
CSM II 51-52). ${ }^{3}$ Since the meditator is explaining what she "perceived by the senses", the meditator's claim that she "regarded" the body as part of herself can be read in a phenomenological register, i.e. as concerning her experience of the body. Malebranche picks up on this phenomenological strain in Descartes, and then runs with it. ${ }^{4}$

This paper examines Descartes's and Malebranche's accounts of the feeling that one human body is mine and part of myself. In the contemporary literature, this feeling is often called a "sense of bodily ownership". ${ }^{5}$ Elsewhere I argue that many factors contribute to this experience. ${ }^{6}$ In this paper, I will focus on the evaluative aspect of our bodily experience. More specifically, I focus on the way affective bodily sensations - such as bodily pleasures and pains, feelings of hunger and thirst, and so on - ground our identification with the body. By characterizing these bodily sensations as affective, I mean to highlight the fact that these sensations feel good or bad. The pleasant sensation of warmth that I experience when I'm sitting by a fire feels good. Hunger feels bad. Nausea feels awful. Intense thirst is torture. Not all bodily sensations are affective, however. Some proprioceptive sensations might be neutral in this regard. For example, my proprioceptive awareness of the position of my limbs - say, that they are crossed - might feel neither good nor bad.

The plan is as follows. First, I sketch Descartes's and Malebranche's accounts of sensory experience as a complicated psycho-physiological process. Second, I clarify the target phenomenon, by explaining the different ways they characterize the sense of bodily ownership. Third, I provide textual evidence that they take affective bodily sensations to make a special contribution to our experiential identification with the body. Fourth, I argue that, according to Descartes and Malebranche, these affective bodily sensations make us feel as though it is good for us to pursue the body's good. This identification with the body's well-being grounds the feeling that the body is part, and perhaps even the whole, of ourselves. In short: we feel embodied because we experience ourselves as having bodily needs and interests.

For the purposes of this paper, I will bracket the question of whether there is any truth in the feeling of bodily ownership, or whether it is a gross illusion. My intention here is simply to focus on this aspect of Cartesian phenomenology. ${ }^{7}$ More

\footnotetext{
${ }^{3}$ See M6, AT VII 76/CSM II 52; M6, AT VII 80/CSM II 56; and Letter to Elizabeth, 28 June 1643, AT III 694/CSMK III 228.

${ }^{4}$ Interestingly, Merleau-Ponty reads Malebranche as a kind of proto-phenomenologist as well (Merleau-Ponty 1968). See for example, Search, V.5, OCM II 172/LO 365; Search, I.12.5, OCM I 137-138/LO 58; Christian Meditations, XI.15, OCM X 122; and DM V.7, OCM XII 118/JS 78.

${ }^{5}$ See Brewer (1995), Martin (1995), de Vignemont (2007).

${ }^{6}$ In my dissertation, I argue that I experience one human body as mine and part of myself because I experience this body as though it were the subject of my mental life. More specifically, I experience one human body as mine because: (1) I experience this human body as the subject of my acts of sensing, (2) I experience this body as the subject of my volitions/inclinations to move this body, and (3) I experience the states of this body as determining my well-being.

${ }^{7}$ Although there has been increasing attention to the metaphysics of the union between mind and body, less attention has been paid to what it is like to be embodied according to the Cartesians. There are a few notable exceptions, however. See, for example: Gueroult (1959), Gouhier (1962),
} 
specifically, my intention is to describe Descartes's and Malebranche's accounts of the way the body is presented in sensory experience from the perspective of the experiencing subject. Apart from its intrinsic interest, the Cartesian phenomenology of embodiment is important for understanding the mind-body union. In his correspondence with Elizabeth, Descartes insists that the senses provide us with our best grasp of the union (Letter to Elizabeth, 28 June 1643, AT III 692/CSMK III 227). ${ }^{8}$ This claim suggests that the way to investigate the nature of the union is to take our ordinary, pre-theoretical experience of embodiment as our starting point, and then to figure out what, if anything, is true in this experience. In other words, we need to purify our bodily experience. But we will only be in a position to determine what is veridical in our experience of embodiment if we know exactly what this experience presents, which is why we need a Cartesian phenomenology of embodiment. This paper, then, lays some of the groundwork for an investigation of the union.

\section{Preliminaries}

According to Descartes and Malebranche, our overall sensory experience is the result of a complicated psycho-physiological process. Descartes distinguishes three grades of sensory response: (1) the stimulation of the sense organs and the resulting alteration in the brain, (2) feelings of pleasure, pain, thirst, hunger, color, sound, taste, and so on, immediately produced in the mind, and (3) habitual judgments that construct the sensory world out of the raw sense impressions of the second stage (O/R 6, AT VII 437/CSM II 294). Suppose I see a turquoise balloon. At the first grade, my eyes and visual cortex are stimulated. Second, an elliptical turquoise patch is consciously presented in my visual field. I will call this a 'sensation'. Third, I judge that the turquoise patch is a turquoise sphere ahead of me, which results in my overall sensory experience as of a voluminous turquoise balloon. I will use the terms 'sensory perception' and 'sensory experience' to refer to the overall conscious result of sensory processing, jointly constituted by the second and third stages, and which together determine the way the sensory world appears to us. ${ }^{9}$

Malebranche agrees with the broad outlines of Descartes' account, though he denies that the mind plays an active role at the third stage (Search, I.10.6, OCM I 129-130/LO 52). He introduces the notion of a "natural judgment" that corrects and enriches the sensory impressions consciously presented at the second stage. Natural judgments construct our sensory experience. We do not make natural judgments for ourselves. Rather, they are hard-wired into our sensory systems, such that they are

\footnotetext{
Merleau-Ponty (1968), Williams (1978), Cottingham (1986), Alanen (2003), Simmons (2003b, 2008), Brown (2006), Carriero (2009), Kolesnik-Antoine (2009), and Curley and Koivuniemi (2015).

${ }^{8}$ Gouhier (1962), Alanen (2003), and Simmons (unpublished) emphasize this point.

${ }^{9}$ For a more detailed account of this process see Simmons (2003a).
} 
"made in us and for us" by God, and needn't involve any assent on our part. Malebranche suggests that we should think of natural judgments as "compound sensations" built up out of simpler sensations, thus highlighting their passivity. ${ }^{10}$ Indeed, Malebranche explicitly distinguishes these natural judgments from the free judgments we make when we culpably affirm that things are as they sensorily appear, whereas Descartes tends to run these two kinds of judgment together.

\section{The Target Phenomenon}

Descartes and Malebranche describe the sensory experience of having a body in many interchangeable ways. They do not draw a sharp distinction, for instance, between experiencing a body (1) as part of me, (2) as mine, and (3) as something I'm united with. Phenomenologically, however, it seems reasonable to blur these characterizations of our bodily experience. Consider, first, the lack of phenomenological distinction between experiencing the body as mine and as part of me. In Meditation 6, the meditator switches between talking about the body she "regarded as part of myself or perhaps even as my whole self" and "the body which by some special right I called "mine"" (M6, AT VII 74-76/CSM II 51-52). Similarly, Malebranche writes: "[God] discloses creatures to us... as belonging to us and forming a part of us when the perception is very interesting and very lively [fort interessante \& fort vive], as is pain" (Elucidations VI, OCM III 66/LO 575). ${ }^{11}$ These passages suggest that, in bodily awareness, there is no felt difference between what is mine and what is part of me.

Descartes and Malebranche aren't simply ignoring the metaphysical distinction between ownership and partial constitution. Something can be mine in different ways. A pair of socks is mine if it is my property. A hand is mine if it is part of my body. An action is mine if I perform it. A thought is mine if I think it. A mind is mine if it is the subject of my mental life. Sometimes being mine implies being part of me, whereas sometimes it doesn't. My socks are mine, but not part of me, whereas the sense in which my mind is mine implies that it is part, and perhaps even the whole, of myself. Crucially, the experiential mine-ness of my body is more like the mine-ness of my mind than the mine-ness of my socks: I experience one human body as mine in the sense that I experience this body as partially constitutive of myself. That's why Descartes claims that it is "by some special right" that I call a single human body "mine" (M6, AT VII 74-76/CSM II 51-52). A special form of ownership is at issue here.

Descartes and Malebranche also deny that there is a sharp phenomenological distinction between experiencing the body as part of me, and experiencing myself as

\footnotetext{
${ }^{10}$ See Search I.7.4, OCM I 97/LO 34; Search I.9.3, OCM I 116/LO 45; and Search I.14.1, OCM I 156/LO 68.

${ }^{11}$ See also Search V.5, OCM II 172/LO 365.
} 
joined or united to a body. Descartes holds that experiencing oneself as united to something generally implies experiencing it as part of oneself. In the Passions, for example, he writes:

considering [his children] as other selves [considerant comme d'autres soy-mesme], [a good father] seeks their good as he does his own, or even more assiduously. For representing that he and they together form a whole [se representant que luy \& eux font un tout] of which he is not the better part, he often puts their interests before his own and is not afraid of sacrificing himself in order to save them. ${ }^{12}$

Because the good father represents himself as united to his children in such a way that "he and they together form a whole", the father's sense of self expands to include his children. Malebranche explicitly applies the general phenomenological principle to the body: "through the instinct of sensation, I am persuaded that my soul is joined to my body, or that my body forms part of my being" (Search V.5, OCM II 172/LO 365).

Again, there seems to be an important metaphysical difference between union and partial constitution. If I am handcuffed to a chair, I am united to it in some sense, but the chair does not thereby become part of me. But just as there are many forms of ownership, so too there are many different forms of union (Letter to Chanut, 1 February 1647, AT IV 610/CSMK III 310). Some forms of union imply that one entity is engulfed and incorporated by another entity, whereas other forms of union do not. When a man gets drawn into a crowd, for example, the crowd swallows him up, so that this individual becomes merged with the group. Similarly, when I experience a body as something that is united to me, I seem to envelop this body, so that the phenomenological limits of myself expand to include it. I read Descartes as making this point in the famous "pilot in a ship" passage in Meditation 6:

[n]ature also teaches me, by these sensations of pain, hunger, thirst and so on, that I am not merely lodged in my body as a sailor is in his ship, but that I am very closely joined and, as it were, intermingled with my body, so that I compose one thing with it. (M6, AT VII 81/ CSM II 56)

When Descartes writes that I am "as it were, intermingled" with my body, he is saying (at least) that I am experientially united to my body in such a way that my body feels like it is part of myself, like a raindrop coalescing into the ocean.

Descartes and Malebranche do not merely recognize that I experience one human body as part of myself, mine, and united to me. They provide an account of this experience, by identifying more basic aspects of our sensory experience on which our overall sense of bodily ownership depends. What they give us, in effect, is an analysis of the structure of the phenomenology of embodiment. In the remainder of the paper, I will explain the role that affective bodily sensations play in this structure.

\footnotetext{
${ }^{12}$ Passions II.82, AT XI 389/CSM I 357. See also Letter to Chanut, 1 February 1647, AT IV 613/ CSMK III 312.
} 


\section{Bodily Sensations and the Sense of Self}

Bodily sensations seem to play a critical role in explaining our sense of bodily ownership. I see, touch, hear, and smell many human bodies, but there is only one human body in which I experience bodily sensations, such as pleasurable sensations and pains, hunger and thirst, and proprioceptive and kinesthetic sensations. This body is the body that I experience as mine, and many philosophers have argued that bodily sensations somehow explain our experiential identification with the body. ${ }^{13}$

Both Descartes and Malebranche maintain that my sense that one human body is mine and part of myself is grounded in bodily sensations. ${ }^{14}$ More specifically, they attribute a special role to affective sensations felt to be located in the body: namely, the sensations of pleasure and pain, hunger and thirst, which feel good or bad. This emphasis on the affective aspect of bodily sensations - their felt goodness or badness - sets Descartes and Malebranche apart from most contemporary discussions of the sense of bodily ownership, which tend to assume that bodily sensations ground a sense of ownership insofar as they present the body from a peculiar internal spatial perspective, i.e. "from the inside". Why Descartes and Malebranche focus especially on affective bodily sensations is a question I will take up in the next section. For now I'm just trying to establish the interpretive claim that they do focus on this subset of bodily sensations.

Let's start with Descartes. When the meditator explains her reasons for identifying with one human body in Meditation 6, the bodily sensations she cites all feel good or bad to some degree. They all have an affective aspect:

[as] for the body which by some special right I called 'mine', my belief that this body, more than any other, belonged to me had some justification [...]. I felt all my appetites and emotions in, and on account of, this body; and finally, I was aware of pain and pleasurable sensations [titillationem voluptatis] in parts of this body, but not in other bodies external to it (M6, AT VII 76/CSM II 52, translation mine)

Since the meditator is reviewing the pre-philosophical beliefs she formed by taking her sensory experience at face value, we can read this passage as describing the contents of her sensory experience. My experience of "this body" as mine is to be explained, at least in part, by the fact that I experience "all my appetites" as well as "pain and pleasurable sensations" as located in it (ibid.). ${ }^{15}$ Crucially, appetites, pains

\footnotetext{
${ }^{13}$ See, for example, Merleau-Ponty (1945), Brewer (1995), Martin (1995), Cassam (1997), de Vignemont (2007), Valberg (2007), and Johnston (2010).

${ }^{14}$ For relevant texts in Descartes, see M6, AT VII 76/CSM I 52; M6, AT VII 80/CSM II 56; Letter to Elizabeth, 28 June 1643, AT III 694/CSMK III 228; and Passions I.24, AT XI 347/CSM I 337. For similar texts in Malebranche, see Search I.12.4, OCM I 137/LO 57; Search I.12.5, OCM I 138-139/LO 58; Search V.5, OCM II 172/LO 366; Elucidations VI, OCM III 66/LO 575; Treatise on Morality I.10.5, OCM XI 118; DM V.7, OCM XII 118/JS 78; and Dialogues on Death II, OCM XIII 408-409.

${ }^{15}$ For the purposes of this paper, I bracket the contribution the passions make to our sense of bodily ownership. That being said, it is unclear whether Descartes is drawing a sharp distinction between passions and other bodily sensations in this context.
} 
and pleasurable sensations are all examples of bodily sensations that feel good or bad. Thirst, for example, is an unpleasant sensation that prompts me to drink. These affective bodily sensations make this body feel like my body, or this body feel like part of me. Similarly, in the "pilot in a ship" passage quoted above, Descartes claims that my "sensations of pain, hunger, thirst and so on" teach me that "I am very closely joined, and as it were, intermingled" with one human body (M6, AT VII 81/ CSM II 56). More than anything else, pain rivets one's sense of self to the body. ${ }^{16}$

Malebranche too emphasizes the special role of affective bodily sensations in explaining the feeling that one human body is mine and part of myself, although his terminology tends to obscure this aspect of his view. In the Search, Malebranche claims that it is specifically "strong and lively sensations" that make one human body feel like part of myself. He writes:

strong and lively sensations startle [étonnent] the mind and rouse [réveillent] it with some force, because they are very agreeable or very disagreeable [fort agréables ou fort incommodes]: such are pain, pleasurable sensations [chatouillement], extremes of heat or cold, and generally all those accompanied not only by traces in the brain but also by movements of spirits toward the body's interior parts, i.e., by a movement of spirits conducive to changing the body's position and to exciting the passions. ${ }^{17}$

For strong and lively sensations, "the soul can hardly prevent itself from recognizing that they belong to it in some way" (Search I.12.5, OCM 138-139/LO 58). Because these sensations are experientially confused with the body, we thereby feel that the body "belongs to us" and is "part of ourselves" (ibid.). ${ }^{18}$

Although Malebranche is very clear that strong and lively sensations confer a sense of bodily ownership, it is much less clear what the defining feature of this category is supposed to be, in virtue of which these sensations make us identify with the body. We might be tempted to assume that their defining feature is that they are perceptually vivid or attention-grabbing: why else would Malebranche call them "strong and lively"? ${ }^{19}$ But it would be a mistake to yield to this interpretive temptation. In fact, a careful reading of the texts reveals that the explanatorily fundamental feature of these sensations is that they are pleasurable or painful, i.e. that they feel good or bad..$^{20}$ The expression "strong and lively sensations" is an awkwardly chosen term of art, and should not be interpreted too literally.

\footnotetext{
${ }^{16}$ Simmons (2008) offers an alternative reading of this passage, according to which Descartes' view is that these bodily sensations confer a sense of bodily ownership in virtue of the fact that these sensations are interoceptive.

${ }^{17}$ Search I.12.4, OCM I 137/LO 57. I translate 'chatouillement' as 'pleasurable sensation' in this context, rather than the more literal 'tickling'. In the Treatise Descartes defines 'chatouillement' as "a certain bodily pleasure [une certaine volupté corporelle]" which "is very close to pain in respect of its cause but quite opposite in its effect" (Treatise, AT XI 144/CSM I 103).

${ }^{18}$ See also Search I.12.5, OCM I 138-139/LO 58; Search V.5, OCM II 172/LO 366; Elucidations VI, OCM III 66/LO 575; Treatise on Morality I.10.5, OCM XI 118; DM V.7, OCM XII 118/JS 78; and Dialogues on Death II, OCM XIII 408-409.

${ }^{19}$ Simmons (2008) reads Malebranche this way.

${ }^{20}$ Gueroult (1959, v. III, p. 52) recognizes this point.
} 
Consider the passage where Malebranche introduces the concept of strong and lively sensations: "[s]trong and lively sensations are those that startle and forcefully rouse the mind because they are either quite pleasant or else very unpleasant (fort agréables ou fort incommodes)" (Search I.12.4, OCM I 137-138/LO 57, emphasis mine). This passage suggests that the defining feature of strong and lively sensations is that they are "quite pleasant or very unpleasant", and attention-grabbing only as a result. Similarly, in the Dialogues on Death, Malebranche writes:

if the idea that you have of that wall struck you with a sentiment of pain, instead of touching you only with a sensation of whiteness, you would regard that wall as part of yourself: because you cannot doubt that pain does not belong to you, as you can now with regards to whiteness. Because not having now a clear idea, neither of your soul nor of your modifications, you judge only by sentiment. Now you feel well that pain belongs to you, because it makes you unhappy: and you do not feel that color belongs to you, because it doesn't do you any benefit or harm. (Dialogues on Death II, OCM XIII 408-409, emphasis mine) ${ }^{21}$

Bodily sensations confer a sense of ownership insofar as they make us happy or unhappy. And that is just to say that bodily sensations confer a sense of ownership insofar as they are pleasurable or painful, or, more generally, insofar as they are affective (Treatise on Morality I.10.8, OCM XI 119).

Interestingly, Malebranche also seems to be committed to the claim that strong and lively sensations are intrinsically motivational, in virtue of their affective character. This claim follows from his background view that pleasure and pain set the will in motion. In the Search, for example, he writes that "if one takes pleasure in general, insofar as it contains intellectual (raisonnables) pleasures, as well as sensible pleasures, it seems certain to me that it is the principle or unique motive of natural love, or of all the movements of the soul towards whatever good there might be, since we can only love what pleases" (Search IV.5.2, OCM II 47/LO 288). Moreover, the texts bear out the interpretive claim that strong and lively sensations - which ground the sense of bodily ownership - are intrinsically motivational for Malebranche. For example, he writes that strong and lively sensations "forcefully rouse the mind" because they are "quite pleasant or very unpleasant" (Search I.12.4, OCM I 137-138/LO 57). Similarly, he claims that "lively and interesting sensations must be felt in the pricked finger in order to pull it away, and not the pin" (Search I.11.3, OCM I 133/LO 55). ${ }^{22}$ These sensations enliven and interest the will, such that they motivate us to act in certain ways.

\section{What Is Special About Affective Bodily Sensations?}

Why might Descartes and Malebranche insist that affective bodily sensations are the key to our sense of embodiment? Why do sensations that feel good or bad - like pain, pleasure, hunger, thirst and so on - make the body in which they are felt to be

\footnotetext{
${ }^{21}$ See Search V.5, OCM II 172/LO 366.

${ }^{22}$ See $D M$ V.7, OCM XII 118/JS 79.
} 
located seem to be part of myself? My proposal is that the projection of affective bodily sensations onto the body makes me feel as though my well-being consists in the preservation of the body. In other words, according to Descartes and Malebranche, we feel embodied because we experience ourselves as having a bodily good. When I step on a nail, for example, I feel a sharp stab of pain located in the foot. The painful sensation grounds my feeling that the foot is part of myself because this experience represents damage to the foot as though it were damage to me.

I read Descartes as endorsing this account of bodily ownership when the meditator rediscovers her body in Meditation 6. The meditator describes her experience as follows:

[t]here is nothing that my own nature teaches me more vividly, than that I have a body, which is damaged when I feel pain, which needs food and drink when I am hungry or thirsty, and so on. So I should not doubt that there is some truth in this. ${ }^{23}$

The meditator's nature doesn't simply teach her that she has a body, full stop. On the contrary, the meditator experiences herself as having a-body-with-needs-to-be satisfied, or as having a-body-with-interests-to-be-pursued. Her experience of having a body and her experience of the body's needs and interests are not distinct from one another; rather, she experiences the body as belonging to her and as part of herself in virtue of experiencing its needs and interest - that is, in virtue of her painful awareness of the body's damage, her unpleasant awareness of its need for food and drink, and so forth.

Descartes's meaning is obscured by the standard translation by Cottingham, Stoothoff and Murdoch (CSM), which reads as follows: "[t]here is nothing that my own nature teaches me more vividly than that I have a body, and that when I feel pain there is something wrong with the body, and that when I am hungry or thirsty the body needs food and drink, and so on" (M6, AT VII 80/CSM II 56). The problem with the CSM translation is that it presents the teachings of nature as a laundry list, without any significant connection between them. It suggests that the meditator's discovery that she has a body is distinct from the feeling of pain that makes her aware that something is wrong with her body. But the original Latin text and French translation seem clear that nature teaches the meditator that she has a body through the feelings of pain, hunger, and thirst that disclose the body's needs. We discover that we have a body because we become aware of the body's interests, just as we might simultaneously learn that a man exists and is in trouble when we hear him call for help. ${ }^{24}$

Moreover, the meditator's experience of the body's needs is personal. There is all the difference in the world between seeing that someone else is thirsty and needs a drink - for example, because he is drenched in sweat on a hot day - and feeling

\footnotetext{
${ }^{23}$ M6, AT VII 80/ CSM II 56. Here is the Latin and French: "quam quod habeam corpus, cui male est cum dolorem sentio, quod cibo vel potu indiget, cum famem aut sitim patior, \& similia/que j'ai un corps qui est mal disposé quand je sens de la douleur, qui a besoin de manger ou boire, quand j'ai les sentiments de la faim ou de la soif, etc." (M6, AT VII 80/CSM II 56).

${ }^{24}$ After developing this reading of Descartes on my own, it was brought to my attention that John Carriero also makes this point in his book Between Two Worlds (2009, p. 393).
} 
thirsty oneself. Crucially, the meditator experiences the body's needs as though they were her own. When the body needs drink, the meditator feels like she needs to find a glass of water, even though it is really the body that is dehydrated. As the meditator explains, when the body's throat is dry:

this sets in motion the nerves of the throat, which in turn move the inner parts of the brain. This motion produces in the mind a sensation of thirst, because the most useful thing for us to know about the whole business is that we need to drink for the conservation of our health. (M6, AT VII 88/CSM II 61, emphasis mine)

Similarly, when the body needs food, she feels hungry, even though, qua immaterial mind, she doesn't need anything to eat. And when the body is damaged, she feels pain, which makes her feel as though she should protect the body. More generally, affective bodily sensations represent the body's needs and interests - the body's good and evil - as belonging to the meditator. As Descartes writes in the Passions, pleasurable sensations represent the "body's healthy condition and strength [...] as a good which belongs to [the soul] in so far as it is united with the body" (Passions II.94, AT XI 399/CSM I 362). Pleasure doesn't simply feel good: it somehow represents the body's health as good for me. I feel healthy when my body feels healthy. Similarly, with regards to pain, he writes that it "represents [bodily damage and weakness] as evils which are always unpleasant to the soul" (ibid., emphasis mine). ${ }^{25}$

Although extremely suggestive, Descartes's account is sketchy. He points out that we experience the body's needs as our own. But he doesn't really explain why or how. He doesn't really explain, for example, how feeling a painful sensation as localized in the body makes it feel as though the body's damage is damage to me. Fortunately, Malebranche fills in some of the details, in a way that seems to be in keeping with Descartes's original insights. Malebranche follows Descartes in claiming that the experience of the body's interests as my own grounds my experience of the body as part of myself. He writes:

[a]t the present time nature is undoubtedly corrupted - the body acts too forcefully on the mind. Instead of humbly representing its needs to the mind, the body tyrannizes it and tears it away from God, to whom it should be inseparably united, and unceasingly applies the

\footnotetext{
${ }^{25}$ Carriero recognizes that, according to Descartes, we experience our body's interest as our own, and reads him as making this point in the famous "pilot in a ship" passage (Carriero 2009, p. 394). That being said, Carriero suggests that the mind has an antecedent concern for the body that explains why the mind takes the body's interests and needs as its own. He writes, "God's setting things up so that the cognitive agent's confused cognition of its hurt foot registers as unpleasant works best against a background where it cares about its body, so that the body's bads, goods, and needs are its bads, goods, and needs" (Carriero 2009, p. 395, emphasis mine). In contrast, I think we should reverse the order of explanation. On my reading, the reason the mind cares so much about the body is precisely because the mind experiences the body's needs as its own. Shapiro also argues that, according to Descartes, the mind "takes" the body's interests as its own, although she seems to think of this "taking" as something we actively do (Shapiro 2003, 2011). See also Louis de la Forge, who seems to read Descartes in the same way as I do (La Forge 1666, Chap. 14, p. 213).
} 
mind to the search after sensible things that might be of use in its preservation. After the Fall, the mind became, as it were, material and terrestrial. ${ }^{26}$

Because the mind phenomenologically identifies its own interests with the body's preservation, and experiences the body's needs as though they were its own, the mind becomes "as it were, material and terrestrial" in the sense that we experience the body as part, and perhaps even the whole, of ourselves (ibid.). ${ }^{27}$ But Malebranche pushes his analysis a bit further than Descartes, by explaining why experiencing affective bodily sensations - namely, pleasure and pain - as located in the body makes us feel as though the body's interests are our own.

According to Malebranche, our fundamental interest consists in experiencing pleasure and avoiding pain. ${ }^{28}$ Note that in the subsequent discussion I will follow Malebranche in using the terms 'interest', 'well-being', and 'happiness' as equivalent. In the Search, for example, Malebranche writes that "pleasure is the way of being that is the best and the most agreeable to the soul: I say pleasure precisely, taken as pleasure [je dis le plaisir précisement, en tant que plaisir] [...] pleasure is well-being [le plaisir est le bien-être]" (Search IV.5.2, OCM II 47-48/LO 288). Similarly, in the Treatise on Morality, Malebranche equates happiness with "actual pleasure", and unhappiness with pain. ${ }^{29}$ But he also argues that we experience pleasure and pain as though they were states of the body. In the Dialogues, for example, he writes: "it seems to me that it is my finger which feels the pain of a prick". ${ }^{30}$ Putting these two claims together, it follows that we experience our fundamental interest as consisting in the body's state. Assuming that we are naturally concerned with our own well-being, this experiential confusion will channel our concern for our well-being towards the preservation of the body.

We can think of this sensory experience as having the following argumentative structure, where the premises combine to produce the compound sensation that is my overall sensory experience:

(1) I experience my pleasures and pains as determining my happiness.

(2) I experience my pleasures and pains as though they were the states of a single human body.

Therefore,

(3) I experience the states of this body as determining my happiness.

\footnotetext{
${ }^{26}$ Search V.1, OCM II 130/ LO 339. See also Preface to the Search, OCM I 11/LO xxxiv; Search I.12.3, OCM I 137/LO 57, and OCM XIV 15.

${ }^{27}$ Interestingly, Malebranche argues that it is a quite general phenomenological principle that if I phenomenologically identify with something's interests, I will thereby experience this thing as part of myself (Search IV.13.1, OCM II 114/LO 330).

${ }^{28}$ See Alquié (1974), Chap. VIII-C, for helpful discussion.

${ }^{29}$ Treatise on Morality I.10.8, OCM XI 119. See Treatise on Morality II.2.11, OCM XI 164; and II.14.1, OCM XI 269.

${ }^{30}$ DM I.1, OCM XII 33/JS 6. See Search I.12.3, OCM I 137/LO 57; Search I.12.4, OCM I 139/LO 58; and Search II.i.5.1, OCM I 215/LO 102.
} 
When I stub my toe, for example, I experience the resulting painful sensation as something that is in my interests to avoid. The pain is "an evil and makes actually unhappy the one who suffers it, in the instant that he suffers it, and to the extent that he suffers it" (Search IV.10.1, OCM II 80/LO 309). But my painful sensation is experienced as a state of the foot. Thus I experience the damage in the foot as "an evil" that makes me "actually unhappy", and that is in my interests to alleviate (ibid.).

More specifically, the experiential confusion of pleasure and pain with states of the body leads us to identify our happiness with the preservation of the body. Our sensory system is hard-wired in such a way that it seems as though pleasure is bodily flourishing or health, and pain is bodily damage or sickness. This is perhaps clearest in the case of pain. As Malebranche writes:

[i]t must be noted that, our senses having been given to us for the conservation of our body, it is very appropriate that we [naturally] judge as we do with regards to sensible qualities. It is much more advantageous to feel pain and heat as though they were in our body, than if we judged that they were in the objects which caused them, because [the changes in the sensory organs accompanying] heat and pain are capable of harming our members, it is appropriate that we are warned when they are threatened, in order to prevent them from being damaged. ${ }^{31}$

Similarly, it is important that we feel pleasure when our body is healthy and in good condition, so that we maintain it in this state (Search V.3, OCM II 157/LO 355; Search V.4, OCM II 161/LO). Even Adam, before the Fall, "felt [ressentoit] pleasure in that which perfected his body" (Search I.5.1, OCM I 71/LO 19). Thus pleasure and pain "interest [the mind] in the body's preservation" (DM IV.20, OCM XII 104/JS 67)..$^{32}$

The experiential confusion cuts in both directions: pleasure is experienced as a state of the body, and bodily health as an intrinsically pleasant qualitative state (and similarly for pain). From this it follows that our happiness seems to consist in maintaining the body in a healthy state conducive to its preservation, which is tantamount to saying that we phenomenologically identify with the body's interests. As Malebranche writes, "[the soul] takes the good of the body for its own good, loves it, and attaches itself to it still more closely with its will than it has ever been attached by nature's initial arrangement" (Search V.4, OCM II 163/LO 360). ${ }^{33}$ It feels as though my good and my body's preservation are one and the same.

Just to be clear, Malebranche's considered view is not that our phenomenological identification with the body's good occurs in two distinct stages: we do not have a prior awareness of the body's interests such that the projection of pleasure and pain subsequently leads us to identify with these interests and take them as our own. On the contrary, I first discover that my body is damaged, for example, when I experi-

\footnotetext{
${ }^{31}$ Search I.12.5, OCM I 142/LO 60. See Search I.5.1, OCM I 72/LO 21; Search I.10.5, OCM I 126-127/LO 51; Search V.4, OCM II 161/LO 359; and Christian Conversations, OCM IV 37.

${ }^{32}$ See Search I.10.5, OCM I 127-128/LO 51-52; and Elucidations XV, OCM III 226-227/LO 670.

${ }^{33}$ See Search III.i.1.2, OCM I 385/LO 200; and Search V.5, OCM II 172/LO 365.
} 
ence my body's state as painful. And I cannot help but experience this painful-stateof-the-body as taking a toll on my happiness. Malebranche writes:

if we put a hot coal in the hand of a sleeping man, or heated his hands behind his back. [...] It seems to me that it is indubitable that the first thing that this man would perceive [appercevroit] as soon as the coal touched his hand would be pain. (Search III.i.1.3, OCM I 387/ LO 201)

Our most basic awareness of the body's needs comes with the identification built right into it.

This account seems to face an obvious objection. The objection is that not all pleasant and unpleasant sensations make us identify with the interests of the entity in which they are felt to be located. For example, a cupcake tastes pleasant and makes me happy, but I do not thereby feel like the cupcake's interests are my interests, or that the cupcake is part of me. So what's the difference between a pleasurable feeling of warmth in a foot, which grounds my identification with the entity in which it is felt to be located, and the pleasant taste of the cupcake, which does not?

One crucial difference is that I literally feel pleasure as located in the foot, whereas I do not literally experience pleasure as located in the cupcake. In fact, Malebranche seems to hold that I only feel pleasurable and painful sensations as located in the human body which I consequently experience as mine. He writes:

[t] he most general cause of the errors of our senses is [...] that we attribute the soul's sensations to external bodies and to our own body: that we attach colors to the surfaces of bodies; that we spread light, sounds and smells in the air; and that we fix pain and pleasurable sensations [la douleur et le chatouillement] in the parts of our body, which receive certain changes from the movements of [external] bodies they encounter. (Search V.6, OCM II 178/ LO 370, emphasis mine)

We feel pain as located in the finger that is pricked, for example, rather than in the pin that pricks it (Search I.11.2, OCM I 132/LO 54).$^{34}$ We might perceive the pin as harmful, as disagreeable, as to-be-avoided, or as containing a disposition to produce pain. But we do not perceive the pin as painful. If I did locate pain in the pin, then I would thereby experience the pin as an extension of my body.

Similarly, when I bite into the cupcake, I experience pleasure diffused throughout the mouth, tongue, and perhaps the rest of my body, rather than as contained in the cupcake. I may experience the cupcake as containing a disposition to produce pleasure. But I do not experience pleasure located inside the cupcake. Thus Malebranche can respond to the cupcake objection by emphasizing that, on his account, we only identify with those objects in which pleasure and pain are felt to be located. Although I experience the cupcake as giving me pleasure, the pleasure itself is not sensorily located in the cupcake. So the cupcake does not provide a counterexample to his account.

\footnotetext{
${ }^{34}$ See Search I.11.3, OCM I 132/LO; Search I.12.5, OCM I 142/LO 60; and Dialogues VI.3, OCM XII 136.
} 


\section{Conclusion}

According to Descartes and Malebranche, affective bodily sensations - such as pain, pleasurable sensations, hunger and thirst - are the key to our sense of embodiment. These bodily sensations make me feel as though it is in my interests to pursue the body's interests, which grounds the experience of the body as belonging to me and as part of myself. More specifically, Malebranche argues that although pleasure and pain are really states of mind, they are experienced as though they are located in, and modifications of, the body. Pleasure is experientially confused with bodily health/flourishing, and pain with bodily illness/damage. This confusion makes us experience our happiness as consisting in the preservation of the body, which, Malebranche suggests, explains why we experience the body's interests as our own. In other words, we feel embodied because we feel like we have a bodily good.

This phenomenological result raises an important question: according to these Cartesians, does our experience of being partially constituted by a body, and as having a bodily good, contain any truth? The short answer is: yes. There has to be some truth in the sense of bodily ownership. If we take seriously the meditator's claim in Meditation 6 that "everything that I am taught by nature contains some truth," then the sense of bodily ownership cannot be wholly illusory (M6, AT VII 80/CSM II 56). Indeed, the meditator goes on to say that " $[t]$ here is nothing that my own nature teaches me more vividly, than that I have a body. [...] So I should not doubt that there is some truth in this" (M6, AT VII 80/ CSM II 56, emphasis mine). What is much less clear, however, is what this truth might be. Hard philosophical work is required to sort out what is true and what is false in this experience. And that is a task for another day. ${ }^{35}$

\section{Bibliography}

In the notes and text, I use the following abbreviations and short titles:

Discourse: Descartes, Discourse on Method/Discours de la Méthode in AT VI.

Elucidation: Malebranche, Elucidation on the Search After Truth/Éclaircissements sur la Recherche de la Vérité in OCM III.

DM: Malebranche, Dialogues on Metaphysics and Religion/Entretiens sur la Métaphysique et sur la Religion in OCM XII.

M: Descartes, Meditations on First Philosophy/Meditationes de Prima Philosophiae in AT VII. $O / R$ : Descartes, Objections and Replies to Objections in AT VII.

\footnotetext{
${ }^{35}$ An early version of this paper was presented at the Subjectivity, Selfhood, and Agency conference at the University of Uppsala, and I am grateful for the many helpful criticisms and questions I received from the audience there. I also owe a debt of gratitude to the many people who have helped me by reading various drafts of this material: Jean-Pascal Anfray, Delphine KolesnikAntoine, Jeff McDonough, Sam Newlands, Sandrine Roux, Tad Schmaltz, and Susanna Siegel. A special thanks goes to Alison Simmons, for all her help along the way, her extensive comments and advice at every step of the process, and, perhaps most of all, her path-breaking work on the Cartesian phenomenology of embodiment.
} 
Passions: Descartes, Passions of the Soul/Les Passions de l'Ame in AT XI.

Principles: Descartes, Principles of Philosophy/Principia Philosophia in AT VIII.

Search: Malebranche, Search After Truth/Recherche de la Vérité in OCM I-II.

Treatise: Descartes, Treatise on Man/L'Homme in AT XI.

\section{Primary Sources}

de La Forge, L. (1666). Traité de l'esprit de l'homme. Amsterdam (Reprint New York: Georg Olms Verlag (1984)).

de La Forge, L. (1997). Treatise on the human mind. (trans: Clarke, D. M.). Boston: Kluwer.

Descartes, R. (1972). Treatise on man. (trans: Hall, T. S.). Cambridge, MA: Harvard University Press.

Descartes, R. (1984-1985). The philosophical writings of Descartes (Vol. 2). (trans: Cottingham, J., Stoothoff, R., \& Murdoch, D.). Cambridge: Cambridge University Press. (= CSM).

Descartes, R. (1991). The philosophical writings of Descartes. Vol. III, The correspondence. (trans: Cottingham, J., Stoothoff, R., Murdoch, D., \& Kenny, A.). Cambridge: Cambridge University Press. (= CSMK).

Descartes, R. (1996). In C. Adam \& P. Tannery (Eds.), Oeuvres de Descartes (Vol. 11). Paris: J. Vrin. = AT.

Malebranche, N. (1967-1999). In A. Robinet (Ed.), Oeuvres complètes de Malebranche (Vol. 20). Paris: J. Vrin. (= OCM).

Malebranche, N. (1980). The Search after truth and Elucidations of the Search after truth (trans: Lennon, T. M. \& Olscamp, P. J.). Columbus: Ohio State University Press. (= LO).

Malebranche, N. (1997). In N. Jolley (Ed.), Dialogues on metaphysics and on religion. (trans: Scott, D.). Cambridge: Cambridge University Press. (= JS).

\section{Secondary Sources}

Alanen, L. (2003). Descartes's concept of mind. Cambridge, MA: Harvard University Press.

Alquié, F. (1974). Le cartésianisme de Malebranche. Paris: Vrin.

Brewer, B. (1995). Bodily awareness and the self. In J. L. Bermudez, T. Marcel, \& N. Eilan (Eds.), The body and the self. Cambridge, MA: MIT Press.

Brown, D. (2006). Descartes and the passionate mind. Cambridge: Cambridge University Press.

Carriero, J. (2009). Between two worlds: A reading of Descartes'Meditations. Princeton: Princeton University Press.

Cassam, Q. (1997). Self and world. New York: Oxford University Press.

Cottingham, J. (1986). Descartes. Oxford: Basil Blackwell.

Curley, E., \& Koivuniemi, M. (2015). Descartes on the mind-body union. In Oxford studies in early modern philosophy. Vol. VII. New York: Oxford University Press.

de Vignemont, F. (2007). Habeas corpus: The sense of ownership of one's own body. Mind and Language, 22(4), 447-449.

Frankfurt, H. (2004). The reasons of love. Princeton: Princeton University Press.

Gouhier, H. (1962). La pensée métaphysique de Descartes. Paris: Librairie J. Vrin.

Gueroult, M. (1955-1959). Malebranche (Vol. 3). Paris: Aubier.

Johnston, M. (2010). Surviving death. Princeton: Princeton University Press.

Kolesnik-Antoine, D. (2009). L'homme cartésien. Rennes: Presses Universitaires de Rennes. 
Martin, M. (1995). Bodily awareness: A sense of ownership. In J. L. Bermudez, T. Marcel, \& N. Eilan (Eds.), The body and the self. Cambridge, MA: MIT Press.

Merleau-Ponty, M. (1945). Phénoménologie de la perception. Paris: Gallimard.

Merleau-Ponty, M. (1968). L'Union de l'âme et du corps chez Malebranche, Biran, et Bergson. Paris: Librairie J. Vrin.

Shapiro, L. (2003). Descartes' Passions of the soul and the union of mind and body. Archiv für Geschichte der Philosophie, 85, 211-248.

Shapiro, L. (2011). Descartes on human nature and the human good. In C. Fraenkel, D. Perinetti, \& J. E. H. Smith (Eds.), The rationalists: Between tradition and innovation. Dordrecht: Springer.

Simmons, A. (2003a). Descartes on the cognitive structure of sensory experience. Philosophy and Phenomenological Research, 67(3), 549-579.

Simmons, A. (2003b). Spatial perception from a Cartesian point of view. Philosophical Topics, 31, 395-423.

Simmons, A. (2008). Guarding the body: A Cartesian phenomenology of perception. In P. Hoffman, D. Owen, \& G. Yaffe (Eds.), Contemporary perspectives on early modern philosophy: Essays in honor of Vere Chappell (pp. 81-113). Peterborough: Broadview Press.

Simmons, A. (unpublished). Mind-body union and the limits of Cartesian metaphysics.

Valberg, J. (2007). Dream, death, and the self. Princeton: Princeton University Press.

Williams, B. (1978). Descartes: The project of pure enquiry. London: Penguin. 